\title{
Francophone literature in search of happiness
}

\author{
Svetlana Nikolajevna Averkina ${ }^{1 *}$, Diana Vladimirovna Mosova ${ }^{1}$, Sergei Matveivich \\ Fomin $^{1}$, and Alexey Sergeevich Shimichev ${ }^{2}$ \\ ${ }^{1}$ Nizhny Novgorod Linguistics University, The Department of Foreign Literature and Intercultural \\ Communication, Nizhny Novgorod, Russia \\ ${ }^{2}$ Nizhny Novgorod Linguistics University, Scientific Laboratory "Magister Posterum”, Nizhny \\ Novgorod, Russia
}

\begin{abstract}
The article deals with modern French-language literature on the loss of a person's sense of happiness and harmony. The study authors explore the work of Western European novelists, who not only record the next decline of Europe but also try to return a sense of dignity to their fellow citizens. For centuries, literature has offered various forms of describing the uniqueness of human interaction with the world. If realism gives rise to a literature of explication that thinks aloud, and modernism tries to free the art of realists from layers of pretense, then the oppositional postmodern aesthetics proposes the so-called pluralism of reading practices, which frees both the reader and the literary critic from the need to search for forerunners and origins. Having experienced postmodern delight at the turn of the 21 st century, the modern Western European writer en masse returns into the fold of realistic literature, in which a person is determined both socially and historically. At the same time, preference is given to documentary literature, which includes both memoirs, diaries, and essays, and the auto-fictional novel, known today as the "non-fiction" novel which has been in the focus of scholars' attention for many years. Whatever forms modern literature may use to disguise itself, even if these forms are the most flowery, its main task is to describe a contemporary who lives with an inescapable feeling of the end of the world, trying to regain the meaning of life, to find footholds that are described in such detail by centuries of aesthetic practice. Therefore, the subject of the study is the classical categories: life, family, love, and peace of mind. The purpose of the study is to describe the current state of literature in Western European countries, identify the trends of its development and genre preferences of the experts of culture. The novelty of the study consists in the fact that the concept of "happiness" is investigated for the first time using the example of French-language literature, and the works of writers little studied in Russian criticism, such as A. Makine and Catherine Lovey, are introduced into academic circulation.
\end{abstract}

Keywords: postmodernism, nonfiction, concept of "happiness", multiculturalism.

\footnotetext{
* Corresponding author: averkina.svetlanalunn@mail.ru
} 


\section{Introduction}

At all times, art, reflecting the world around us, tried to explain the reasons for the dissatisfaction of a person whose ideal did not coincide with the real world. The dream of happiness had to include all possible states of satisfaction and prosperity, wealth, and peace of mind. These are separate facets of the concept "bonheur", which, in general, was understood by all modern Europeans in the same way until recently. However, the 21st century destroyed such uniformity, and all modern literature, trying to understand the causes of instability, suggests ways to return to universal harmony. Writers try to reflect the new reality, either by directly transforming a fictional text into journalism or by looking for footholds in glorious history.

This was already the case in the 19th century, when romanticists, frustrated by new trends in politics, economics, and culture, turned their gaze to the distant and, as they imagined, heroic past, or when realists as social scientists described "social plagues", actively participating in the political life of the country for the sake of their immediate elimination. However, both movements always offered the reader a certain ideal that embodied possible harmony and happiness, even if this destroyed the artistic truth and the logic of character development. Thus, Balzac could not help balancing the image of the vicious Countess de Resto with the almost ideal image of Fanny Malvo. However, if the 19th century, especially its first half, as the Soviet critic wrote, was still a time that had "poetry of negative values" [1:208], then the turn of the century weakened the hope of finding happiness, and the 20th century with its world wars practically destroyed this poetry.

It would seem that the belief in universal happiness was revived in the 21 st century. This hope was generated not only by more than half a century without world wars but also by the European policy of multiculturalism and tolerance, scientific and technological progress, and the development of new cultural techniques and spaces. However, the illusion of universal well-being and European prosperity quickly faded, and the experts of culture were the first to deliver the verdict.

People from different historical eras felt satisfied with life in different ways. For example, for a French aristocrat of the 17th century, a meeting with the King in the gardens or salons of Versailles was considered a truly happy moment in life, and for a medieval knight, a meeting with the beloved. At any rate, by the beginning of the 21 st century, the modern concept of happiness was mainly formed, which, according to a prestigious explanatory dictionary, includes such states of mind as pleasure, well-being, joy, euphoria, ecstasy, etc. [2: 198].

Of interest is a survey of students from the University of Paris 8, conducted at the turn of the 21st century: the respondents had to name the main qualities of a French person. Thus, most respondents identified such properties as gallantry and frugality, self-esteem and adherence to republican values, a spirit of criticism, and a desire for comfort. Respondents unanimously noted the reverent attitude of the citizens of the Fifth Republic to personal freedoms and such a universal quality for all French people as individualism. By and large, all these are facets of the concept of happiness the way it is understood not only in France but also in Europe [3: 40-41].

\section{Methods}

We used the classic methods and approaches to the study and description of literature: biographical, cultural-historical, and comparative-historical, as well as elements of receptive aesthetics. 


\section{Results and discussion}

Modern writers have practically no hope of finding happiness in the current socio-political conditions. The main feature of modern Western European prose, without a doubt, is total pessimism because writers, at least in France, sense and predict the inevitable cataclysms that scientific and technological progress, pandemic, and migration have in store. Therefore, the writers either turn their gaze to the heroic past of France, as, for example, J.M. Guenassia or G. Rouault, or engage in the fantasy genre, as M. Houellebecq does.

In addition, modern "classics", for example, F. Beigbeder or A. Makine, not only write novels but also draw from the arsenal of journalism, which allows one to directly address the reader. For example, in the book "Premier bilan après l'apocalypse" F. Beigbeder talks about the decline of the era of the printed text, arguing that happiness is even further removed from the European who is accustomed to being proud of literary traditions. In Beigbeder's opinion, the very concept of aristocratic spirit, directly connected with French civilization, is being destroyed. The writer is sure that it was "highbrow literature" that made the thinking Frenchman free and happy, "because each book on paper was different from others - an electronic book is indifferent to everything, it does not change its form for the sake of a new novel" [4: 14].

This remark refers to the deep nature of the French national character with its individualism, which is the main component of the French concept of "bonheur". To be happy means to be different from others. Clearly, for most modern French people who are used to the comfort associated with the so-called "consumer society", Beigbeder's idea is questionable, but for the national elite, acting as the protector of the French spirit, it is immutable. At any rate, a galaxy of modern "classical writers" - from F. Beigbeder to E. Carrère, from A. Nothomb and to J. Eschnoze, from G. Rouault to D. Sallenave - is trying to understand the reasons for the inner discomfort of a fellow countryman deprived of happiness.

Many critics point out that the general pessimistic mood affected even the Frenchlanguage literature of Switzerland, a country that, according to all international ratings, leads the ranks of the happiest states, excluding, perhaps, only primitive tribes ("happy aborigines", referring to the categories J.-J. Rousseau's philosophy) who cannot be surveyed [5]. "Swiss happiness" has often become a subject of irony for European neighbors, since the happiness is based on equilibrium bordering on boredom, modesty bordering on detachment, a tendency to orderliness bordering on formalism, as well as "direct democracy, the cleanest toilets and the right to euthanasia" [6]. However, in recent years, the national characteristics of Swiss literature have been increasingly leveled in the context of the pan-European literary process. This is because the very cultural space of Switzerland and France is united by language and a common readership.

The authors investigating the crisis of modern society and the individual's sense of self in society, one can name C. Lovey, whose characters are looking for happiness far beyond the borders of their native canton [7]. D. Loup raises the question of a new loop of dehumanization of mankind: the love of the Swiss for nature turns them into a new type of "educated animal" [8: 12]. In allegorical novellas by J.-M. Lavey debunks the mainstream cultural Swiss myth of the country's actual and spiritual "neutrality" [9]. Loss of balance and general prosperity is the topic of work for A. Grobéty, C. Jeannoux, C. Pascal, D. de Rougemont, J. Chesséx [10-12].

One of the most prominent figures in the gallery of writers who share these sentiments is Andrei Makine, a member of the French Academy, whose opinion on the problems of modern French civilization is of undoubted interest.

A. Makine is the bearer of two cultural codes, and therefore the reasoning of the "outside observer" sounds very sincere, and thus convincing. Despite more than thirty years of his 
"French" biography, the writer remains the successor to Russian culture, which was formed with the influence of the French elite of the 18th -19 th centuries.

A. Makine is a prominent French writer who publishes a novel a year, the winner of the most prestigious literary awards of his new homeland. The writer's personality is phenomenal in every sense: Makine was the only emigrant who received the right to be a member of the French Academy. At the same time, his track record includes a play, a doctoral dissertation dedicated to I. Bunin, and a journalism volume that summarizes all of Makine's novelistic work. In the book "This France we forget to love" ("Cette France qu'on oublie d'aimer"), A. Makine tries to define the concept of "Frenchness", define its specific features and parameters. Among other things, the writer notes the French addiction to the formal side of life. It is "clarity" in everything - ideological purity, the harmony of lines, and transparency of form - for a long time remained for them a guarantee of peace of mind and completeness of personal happiness [13: 95].

Today, according to A. Makine, this harmony is completely gone. The entire collection "This France we forget to love" is another attempt in French literature to return a sense of dignity to fellow citizens, who cannot accept the idea that their homeland is no longer a great power: there is no former vast French world, and no innovations in the policy of the recent decades will succeed [14].

An illustration of the thoughts of Makine the publicist was his novel "Across Borders" (Au delà des Frontières), in which the writer describes the tragic fate of a young Frenchman who committed suicide [15]. After his death, the character's mother tries to publish his fantastic novel-parable about how a generation full of hope lost the fight against a corrupt government and a lack of initiative in society. The narrator, who is discernably A. Makine himself, begins his investigation which ends in the Caucasus mountains where a group of socalled "diggers" live - people who have realized the inevitable balefulness of civilization and the need to create a new world without utopian delusions, traditional religions, politically correct politics, and culture.

The last novel by A. Makine is a novel within a novel as the story opens with the book The Great Exodus, which remained after the death of the protagonist of the novel Beyond the Boundary by Vivien Linden, which the author of the book is trying to publish. This looks like a verdict on modern civilization: everyone who caused irreparable damage to France leaves the country: from presidents to prominent writers, journalists, and corrupt clerks. The new authorities are exiling them to Libya while trying to organize France based on what the authorities see as reasonable principles. Paradoxically, the exiled find happiness because they implement the postulates of a new philosophical doctrine - the "third birth" or metapractice, which returns a person to their origins - nature and simplicity, sincerity and helpfulness, while the French who remained at home continue the disastrous path of losing moral guidelines and the meaning of life.

\section{Conclusion}

The cautionary novel could not but cause controversy in the "sick" West European society. Intense discussions on television and social networks have once again confirmed the idea of French writers that salvation lies in history and culture, that the French language can play a special role - the last thing that still allows us to speak of France as a great power. Therefore, as it was during the Second World War with Vercors' story "The Silence of the Sea", which returned to France the feeling of its former greatness, today the revival of a sense of happiness is possible only based on a centuries-old culture, provided that many sacred values for the French have to be abandoned, particularly those associated with freedom of speech.

It is obvious that the concept of "happiness" has not been sufficiently developed in contemporary critical literature. Attempts to describe the concept are only occasionally found 
in student papers or individual dissertation research as "related" material. This article is the first step towards describing this category of the cultural code of Western European civilization and the emergence of a monographic study of this problem.

\section{References}

1. V.R. Grib, Izbrannoe [Selected works] (GIKhL, Moscow, 1956)

2. Dictionnaire alphabétique et analogique de la langue française par P Robert (S.N.L., Paris, 1979)

3. I. Sokologorski, Frantsuzskoe [The French], in Problemy mezhkulturnoi kommunikatsii [Problems of cross-cultural communication], Part 1, 40-41 (NGLU, Nizhnii Novgorod, 2000)

4. F. Beigbeder, Premier bilan après l'apocalypse [First assessment after the apocalypse] (Azbuka-Attikus, St.-Petersburg, 2014)

5. L. Klot, La nation suisse est la plus heureuse au monde! [The Swiss are the happiest nation in the world!]. Nasha Gazeta (2010). Accessed on: November 9, 2020. [Online]. Available: http://nashagazeta.ch/news/11070

6. E. Weiner, Switzerland: Happiness is boredom, in The Geography of Bliss (Twelve, New York, 2008)

7. C. Lovey, Monsieur et Madame Rivaz (Editions Zoé, Chêne-Bourg, 2016)

8. S.N. Averkina, Inostrannaya Literature [Foreign Literature], 11, 11-114 (2020)

9. J. Francillon, Histoire de la littérature en Suisse romande [History of literature in French-speaking Switzerland] (Payot, Lausanne, 1996-1999)

10. R. Francillon, Littérature en langue française (2014). Accessed on: January 04, 2021. [Online]. Available: https://hls-dhs-dss.ch/fr/articles/011202/2014-12-04

11. P. Rusterholz, A. Solbach, Schweizer Literaturgeschichte (Metzler, Stuttgart, 2007)

12. S. Molla, Jacques Chessex et la Bible: parcours à l'orée des écritures (Labor et fides, Genève, 2002)

13. A. Makine, Cette France qu'on oublie d'aimer (Flammarion, Paris, 2006)

14. S.M. Fomin, P.A. Lyaskov, Literatura XX-XXI vekov. Problemy poetiki.

Kollektivnaya monograifya [Literature of the 20th-21st centuries. Problems of poetics. Collective monograph], 61-76 (Flinta, Moscow, 2020)

15. A. Makine, Au delà des Frontières (Kindle Edition, 2019) 